\title{
Identifikasi Jenis Kapang Kontaminan Kedelai (Glycine max (L.) Merr.) di Pasar Tradisional Kota Malang
}

\section{Identification of Contaminant Fungi Species on Soybean (Glycine max (L.) Merr.) in Malang Traditional Markets}

\author{
Maulita $\mathbf{F}^{\mathbf{1}}$, Hastuti US ${ }^{\mathbf{1}}$, Prabaningtyas $\mathbf{S}^{\mathbf{1}}$ \\ ${ }^{1}$ Laboratorium Mikrobiologi, Jurusan Biologi, Fakultas Matematika dan Ilmu Pengetahuan Alam, Universitas \\ Negeri Malang. Jl. Semarang 5 Lowokwaru 65145 Jawa Timur, Indonesia
}

Maulita F, Hastuti US, Prabaningtyas S. 2021. Identifikasi jenis kapang kontaminan Kedelai (Glycine $\max ($ L.) Merr.) di Pasar Tradisional Kota Malang. Jurnal Mikologi Indonesia 5 (1): 1-6. doi:10.46638/jmi.v5i1.139.

\begin{abstract}
Abstrak
Biji kedelai dapat mengalami kerusakan, antara lain: karena pemanenan yang kurang cermat, serangan serangga hama di lahan pertanian, gigitan serangga di tempat penyimpanan biji sebelum dijual, serta terkontaminasi oleh kapang penghasil mikotoksin di pasar. Fokus dari penelitian ini ialah: 1) mengisolasi dan mengidentifikasi semua jenis kapang kontaminan pada biji kedelai yang dijual di beberapa pasar di Kota Malang, 2) menentukan jenis kapang kontaminan yang paling dominan dalam biji kedelai yang diteliti, dan 3) mengkaji dampak cemaran kapang kontaminan terhadap penurunan kualitas biji kedelai berdasarkan kajian pustaka. Data diperoleh melalui metode observasi, deskripsi, dan identifikasi semua jenis kapang kontaminan yang ditemukan pada biji kedelai yang diteliti. Selanjutnya dilakukan identifikasi dengan deskripsi morfologi koloni dan mikroskopis kapang. Hasil yang diperoleh yaitu tujuh isolat jenis kapang kontaminan, yakni Scopulariopsis brevicaulis, Penicillium frequentans, Aspergillus tamarii, mycelia sterilia I, Aspergillus oryzae, Aspergillus ochraceus, dan mycelia sterilia II; 2) jenis kapang kontaminan yang paling dominan yaitu Aspergillus ochraceus; 3) cemaran kapang berdampak terhadap penurunan kualitas biji kedelai, yaitu: tekstur biji berserbuk, hancur, keriput, berbau apak, dan berpotensi tercemar oleh mikotoksin yang dihasilkan kapang kontaminan.
\end{abstract}

Kata kunci: mikotoksin - mikrobiologi pangan - morfologi kapang

\section{Abstract}

Damage in soybean seed could be, amongst others, caused by: in appropriate harvesting, attack by insect at the farmland, attack by pest insect at the store-house before distribution to the consumers, or contaminated by mycotoxin-producing molds at the markets. The research was focused to: 1) isolate and identify all species of the contaminant mold species in soybean seeds sold at five traditional markets in Malang city; 2) to determine the most dominant contaminant mold in the soybean seeds sample; 3) to study the impact of mold contamination on the soybean quality decrease based on the literature review. The data were obtained observation, description, and identification of all contaminant molds isolated from the soybean seed samples. Each of the contaminant mold isolates were determined and identified based on the colony and microscopic morphology. The results were: 1) seven contaminant mold isolates, namely: Scopulariopsis brevicaulis, Penicillium frequentans, Aspergillus tamarii, mycelia sterilia I, Aspergillus oryzae, Aspergillus ochraceus, and mycelia sterilia II; 2) the most dominant contaminant mold species was Aspergillus ochraceus; 3) contamination by the mold species affected the decrease of soybean seeds quality, i.e.: the presence of powdery seeds, grits, wrinkle, moldy smell and could be contaminated by the mycotoxins produced by the contaminant molds.

Key words: food microbiology - mycotoxin - mold morphology 


\section{Pendahuluan}

Biji kedelai dimanfaatkan untuk pengolahan tahu, tempe, kecap, tauco, susu kedelai cair dan bubuk, serta minyak kedelai (Widowati, 2013). Kandungan nutrisi dalam $100 \mathrm{~g}$ biji kedelai yakni $381 \mathrm{kkal}$, protein $40 \mathrm{~g}$, lemak 16,7 g, dan karbohidrat 24,9 g (Mahmud dkk., 2009). Keunggulan biji kedelai dibanding biji-bijian lain yaitu karena kandungan proteinnya yang mencapai $40 \%$. Biji kedelai yang dijual di pasar maupun warung-warung harus memiliki kerusakan yang minim hingga terhindar dari kerusakan. Kerusakan tersebut bisa terjadi pada saat pemanenan, distribusi, maupun penyimpanan oleh pedagang di pasar dan di gudang. Selain itu, gigitan serangga pada permukaan biji kedelai juga dapat menjadi perantara masuknya spora kapang ke dalam biji (Hastuti, 2010). Pihak yang paling berperan dalam melakukan pencegahan kerusakan morfologi biji kedelai ialah para petani, distributor, dan pedagang (Widiastuti, 2006). Pihak yang paling berperan dalam melakukan pencegahan kerusakan biji kedelai oleh kapang ialah: para petani, distributor, dan pedagang. Inventarisasi kapang kontaminan dari biji-bijian telah diteliti sebelumnya pada beberapa biji.

Kapang kontaminan yang hidup saprofit saat tidak ada inang dan akan bersifat mendegradasi nutrisi pada bahan pangan terutama biji-bijian. Penelitian terdahulu ditemukan kapang Aspergillus sp. dan Penicillium sp. pada biji kacang tanah yang dijual di pasar (Rakhmawati, 2009; Kartana dkk., 2013). Pada penelitian lain juga menyatakan pada kacang hijau, kacang merah, dan biji ketumbar yang terkontaminasi oleh mayoritas Aspergillus sp. dan Penicillium sp. dari pasar tradisional berbagai daerah di Indonesia (Koban dkk., 2011; Qomariah dkk., 2012; Permata, 2018). Hal tersebut menunjukkan bahwa kekhawatiran kepada potensi cemaran mikotoksin akan semakin besar. Selain tanaman dari pertanian, juga terdapat kontaminasi kapang yang berpotensi menghasilkan mikotoksin pada biji kopi (Aaraj et al., 2015; Culliao \& Barcelo, 2015). Aspergillus sp. dan Penicillium sp. ini berpotensi menghasilkan mikotoksin seperti aflatoksin, patulin, sitrinin, okratoksin dan lain-lain (Miskiyah dkk., 2010).

Kontaminasi kapang tidak terbatas hanya pada biji-bijian yang telah disebutkan di atas, masih terdapat banyak jenis biji yang belum diketahui. Salah satu biji-bijian yang sangat dikenal orang Indonesia ialah kedelai yang bermanfaat besar seperti di atas. Kedelai yang dijual di pasar tradisional masih belum banyak diteliti apakah membawa kapang yang berpotensi menghasilkan mikotoksin. Berdasarkan hal tersebut, maka dilakukan penelitian mengenai isolasi dan identifikasi jenis kapang kontaminan pada biji kedelai di Pasar Tradisional Kota Malang, dengan tujuan: 1) mendapatkan isolat kapang kontaminan pada biji kedelai yang dijual di beberapa pasar di Kota Malang, 2) mengidentifikasi sampai tingkat jenis dan 3) melakukan studi pustaka dampak cemaran kapang kontaminan.

\section{MetodePenelitian}

\section{Pengambilan sampel kedelai dan isolasi kapang kontaminan}

Data diperoleh melalui metode observasi, deskripsi, dan identifikasi semua jenis kapang kontaminan yang ditemukan pada biji kedelai yang diteliti. Pasar yang telah ditentukan ialah Pasar Blimbing, Pasar Kedungkandang, Pasar Tawangmangu, Pasar Besar, dan Pasar Mergan. Prosedur ini dimodifikasi dari Qomariah dkk. (2012) yaitu sampel biji kedelai diambil sebanyak $100 \mathrm{~g}$ dari tiap pasar dengan diwakili oleh satu pedagang secara acak terpilih. Pengambilan sampel diulang sebanyak tiga kali dengan interval waktu tiap ulangan dua minggu.

Sampel biji kedelai dibawa ke Laboratorium Mikrobiologi, Jurusan Biologi, FMIPA UM (Universitas Negeri Malang) dengan dimasukkan ke dalam botol selai steril dan disimpan di dalam termos yang berisi es batu. Biji kedelai dicampur masing-masing $10 \mathrm{~g}$ per pasar, lalu diambil sebanyak $10 \mathrm{~g}$, kemudian dihaluskan dengan blender dan selanjutnya 
diencerkan menggunakan media potato dextrose broth (PDB) dan diinokulasikan ke medium lempeng potato dextrose agar (PDA) lalu diinkubasi pada suhu $27^{0} \mathrm{C}$ selama $5-7 \times 24$ jam.

\section{Identifikasi kapang kontaminan}

Identifikasi kapang dilakukan dengan pengamatan ciri morfologi koloni kapang dan ciri mikroskopis kapang, kemudian dirujukkan pada buku kunci identifikasi kapang "Introduction to Food Born Fungi" (Samson et al., 1984) dan "Fungi and Food Spoilage" (Pitt \& Hocking, 1985). Selain itu, dihitung rerata jumlah kapang kontaminan untuk mengetahui jenis kapang kontaminan dominan.

\section{Hasil}

Berdasarkan hasil deskripsi morfologi koloni terhadap tiap-tiap isolat kapang kontaminan pada biji kedelai yang di jual di lima pasar yang ada di Kota Malang diperoleh 7 macam kapang kontaminan (lihat Tabel 1).

Tabel 1. Urutan jenis kapang kontaminan pada biji kedelai berdasarkan rerata

\begin{tabular}{llll}
\hline No & $\begin{array}{l}\text { Kode } \\
\text { koloni }\end{array}$ & Nama jenis kapang & $\begin{array}{l}\text { Rerata jumlah koloni } \\
\text { tiap jenis kapang cfu/g }\end{array}$ \\
\hline 1 & F & Aspergillus ochraceus K. Wilh. & $5,5 \times 10^{5}$ \\
2 & B & Penicillium frequentans Westing & $1,6 \times 10^{5}$ \\
3 & A & Scopulariopsis brevicaulis (Sacc.) Bainier & $1,1 \times 10^{5}$ \\
4 & D & Mycelia sterilia I & $5,5 \times 10^{2}$ \\
5 & G & Mycelia sterilia II & $5,5 \times 10^{2}$ \\
6 & E & Aspergillus flavus var. oryzae (Ahlb.) Kurtzman & $1,2 \times 10^{2}$ \\
7 & C & Aspergillus tamarii Kita & $5,5 \times 10^{1}$ \\
\hline
\end{tabular}

\section{Pembahasan}

Keberadaan kapang kontaminan tersebut dapat disebabkan oleh beberapa faktor yang mendukung pertumbuhan kapang, baik dari dalam biji maupun di lingkungan luar biji, antara lain: aktifitas air (Aw), kelembapan, komposisi nutrient, faktor inhibitor, suhu, serta cara penyimpanan biji-bijian tersebut. Apabila biji-biji mengalami kerusakan fisik dapat memicu terjadinya kontaminasi oleh spora-spora kapang yang ada di lingkungannya pada biji kedelai tersebut. Kerusakan fisik pada biji kedelai akan menurunkan kualitas biji. Kriteria biji yang berkualitas buruk yaitu: biji berlubang, keriput atau berserbuk, biji tidak utuh atau hancur sebagian (Suparyati \& Supriyo, 2015). Biji-biji kedelai yang ditandai dengan ciri-ciri tersebut dapat mengindikasi telah terjadi kontaminasi kapang pada biji tersebut.

Kontaminasi kapang pada biji kedelai dapat terjadi baik pada masa pertumbuhan di lapangan maupun pada saat penyimpanan di gudang. Kontaminasi di lapangan ini disebabkan karena infeksi kapang pada saat tanaman masih tumbuh di lapangan sampai waktu panen misalnya Altenaria spp., Aspergillus spp., Penicillium spp., dan Fusarium spp. (Ahmad, 2009). Berdasarkan hasil observasi yang dilakukan oleh peneliti, diketahui bahwa biji kedelai yang dijual di pasar diletakkan pada kotak dari bahan plastik yang terbuka. Kondisi tempat yang terbuka seperti ini akan memicu kontaminasi dari spora kapang dengan perantaraan serangga hama gudang.

Berdasarkan hasil yang ditemukan (Gambar 1), terdapat jenis Aspergillus tamarii, A. oryzae, A. ochraceus, dan Penicillium frequentans. Jenis yang ditemukan ini digolongkan ke dalam kapang gudang (Ahmad, 2009). Hal tersebut mirip dengan kapang kontaminan pada biji kacang tanah yang didominasi oleh marga Aspergillus dan Penicillium (Rakhmawati, 2009). Kontaminasi oleh Penicillium chrysogenum, $P$. expansum, $P$. citrinum, $P$. camembertii, $P$. nalgiovanse, dan A. niger ditemukan pada kacang hijau, tetapi berbeda dengan kedelai dan kacang tanah yang didominasi oleh Aspergillus sp. (Koban dkk., 2011). Adanya perbedaan dominasi kapang disebabkan oleh berbagai faktor seperti komposisi 
substrat, ketersediaan air, dan suhu. Biji kacang merah didominasi oleh marga Penicillium, yaitu $P$. chrysogenum, $P$. citrinum, $P$. expansum, $P$. rugulosum, $P$. frequentans, dan $P$. verrucosum (Qomariah dkk., 2012)

Jenis Scopulariopsis brevicaulis (Gambar 1) biasanya terisolasi dari tanah, udara, puing-puing tanaman, dan kotoran hewan (Sandoval-Denis et al., 2013; Sandoval-Denis et al., 2016). Kontaminasi oleh kapang-kapang tersebut terjadi saat di lapangan dan pada saat pasca panen. Kapang A. oryzae tidak menghasilkan aflatoksin dan metabolit lainnya yang bersifat karsinogenik, selain itu juga telah lama digunakan untuk membuat kecap dari kedelai. Selain itu ditemukan pula jenis kapang A. ochraceus yang berpotensi sebagai penghasil mikotoksin yaitu okratoksin (Lioe et al., 2010).

Urutan jenis-jenis kapang kontaminan dalam biji kedelai berdasarkan jumlah koloni masing-masing jenis kapang tertera pada Tabel 1.

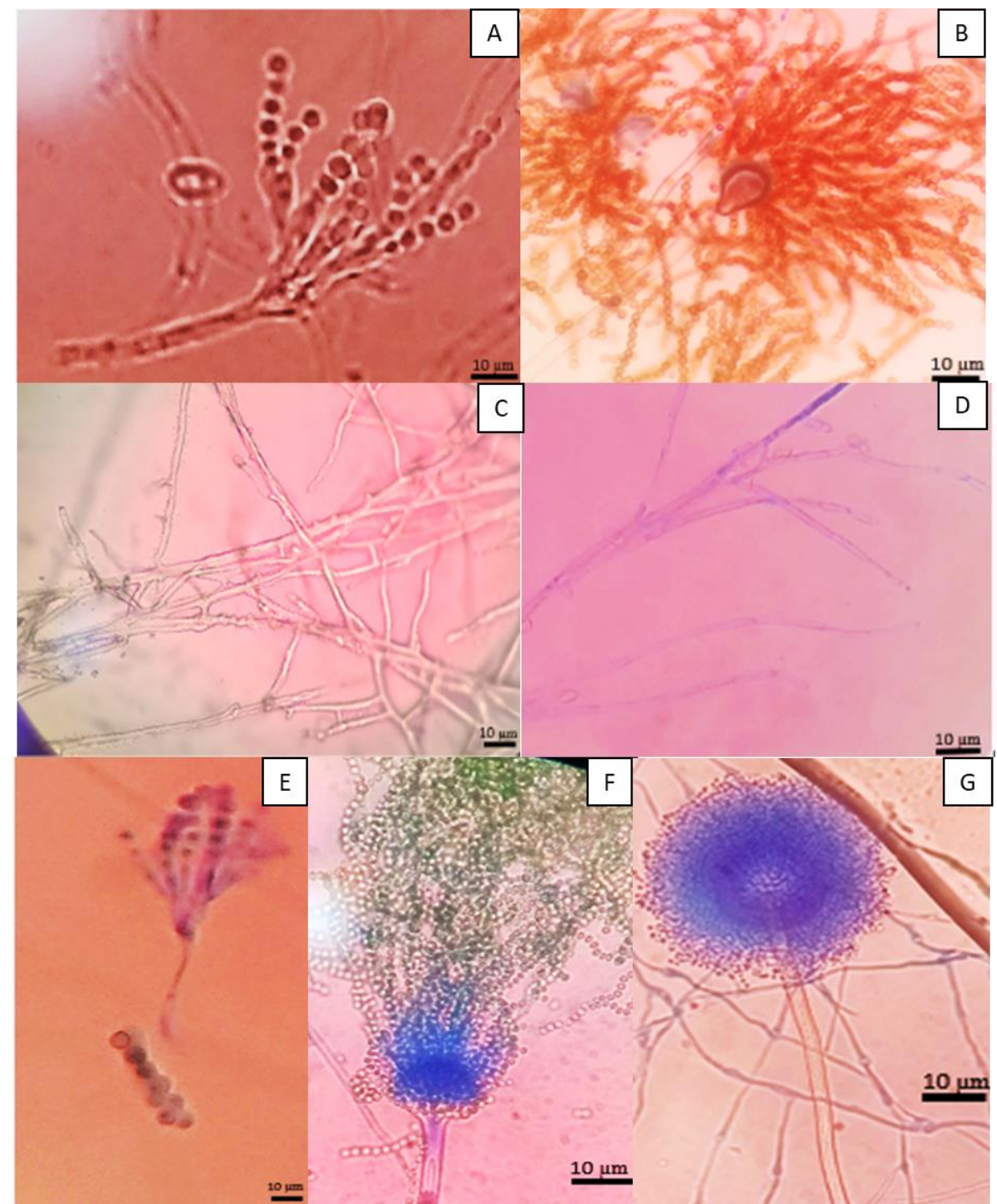

Gambar 1. Jenis-jenis kapang kontaminan pada biji kedelai di lima Pasar Tradisional Kota Malang Keterangan: A) S. brevicaulis, B) A. tamarii, C) Mycelia sterilia I, D) Mycelia sterilia II, E) P. frequentans, F) A. oryzae, dan G) A. ochraceus

Berdasarkan Tabel 1 diketahui bahwa ada satu macam jenis kapang yang paling dominan ditemukan dalam sampel biji kedelai berdasarkan urutan jumlah koloni yang tertinggi yaitu A. ochraceus dengan rerata jumlah koloni jenis kapang tersebut ialah 5,5 x $10^{5}$ cfu/g. Aspergillus ochraceus merupakan kapang yang memiliki potensi penghasil mikotoksin 
yaitu okratoksin pada kondisi tertentu. Okratoksin dapat menyebabkan kerusakan saraf, kerusakan sistem imun, dan dapat menyebabkan kanker (Lioe et al., 2010). Berdasarkan hasil penelitian ini diketahui bahwa jenis kapang kontaminan yang paling dominan dan tumbuh di dalam biji kedelai berpotensi menghasilkan mikotoksin yang berbahaya bagi kesehatan manusia. Penelitian terdahulu menyatakan bahwa A. ochraceus juga paling dominan ditemukan pada biji kopi yang mengalami kerusakan fisik (Aaraj et al., 2015). Hal tersebut dapat menjadi peringatan agar para konsumen cermat dalam memilih biji kedelai yang berkualitas baik yang ditandai dengan ciri-ciri biji utuh, tidak berlubang, dan tidak berserbuk. Kapang tersebut menghasilkan mikotoksin berupa okratoksin yang dihasilkan pada kondisi tertentu.

Kapang kontaminan yang ditemukan dalam sampel biji kedelai pada penelitian ini sebanyak tujuh jenis, yaitu: S. brevicaulis, $P$. frequentans, A. tamarii, mycelia sterilia I, mycelia sterilia II, A. oryzae, dan A. ochraceus. Jenis kapang kontaminan yang paling dominan dalam biji kedelai yang diteliti yaitu A. ochraceus. Cemaran kapang kontaminan berdampak terhadap penurunan kualitas biji kedelai, misalnya: tekstur biji berserbuk, hancur, berkeriput, berbau apak, dan berpotensi tercemar oleh mikotoksin yang dapat dihasilkan oleh kapang kontaminan penghasil mikotoksin.

\section{Ucapan Terimakasih}

Penelitian ini tidak lepas dari dukungan dan bimbingan Prof. Dr. Dra. Utami Sri Hastuti, M.Pd., Ibu Sitoresmi Prabaningtyas, S.Si., M.Si., dan dr. Sulisetijono, M.Si. Selain itu tenaga laboran Jurusan Biologi, FMIPA UM telah membantu secara teknis dalam penelitian, serta asisten dosen Laboratorium Mikrobiologi.

\section{DAFTAR PUSTAKA}

Aaraj, C.E., Bakkali, M., Infantito, A., Arakrak, A. \& Laglaoui, A. (2015). Mycotoxigenic fungi in cereals grains and coffee from the North of Morocco. Am J Res Commun., $3(2), 130-142$.

Ahmad, R.Z. (2009). Cemaran kapang pada pakan dan pengendaliannya. J Litbang Pertanian, 28(1), 15-22.

Culliao, A.G.L. \& Barcelo J.M. (2015). Fungal and mycotoxin contamination of coffee beans in Benguet province, Philippines. Food Addit Contam - Part A Chem Anal Control Expo Risk Assess., 32(2), 250-260. doi:10.1080/19440049.2014.1001796.

Hastuti, U.S. (2010). Prof. Dr. Dra. Utami Sri Hastuti M.Pd : Pidato Pengukuhan Guru Besar dalam Bidang Ilmu Mikrobiologi pada FMIPA Universitas Negeri Malang (UM).

Kartana, I.M, Wisaniyasa, N.W. \& Duniaji, A.S. (2013). Isolasi dan identifikasi kapang pada kacang tanah (Arachis hypogaea L.) yang dijual di beberapa pasar tradisional di Provinsi Bali. Itepa: J Ilmu dan Teknol Pangan, 2(1).

Koban, M.A.G., Suarsini, E. \& Witjoro, A. (2011). Mikoflora kontaminan dan spesies kapang kontaminan dominan pada kacang hijau (Vigna radiata L.) yang dijual di pasar besar Kota Batu. State University of Malang.

Lioe, H.N., Selamat, J. \& Yasuda, M. (2010). Soy sauce and its umami taste: A link from the past to current situation. JFood Sci., 75(3), 71-76. doi: 10.1111/j.17503841.2010.01529.x.

Mahmud, M., Zulfianto, N.R.H, Apriyantoro, I., Ngadiarti \& Hartati, B. (2009). Tabel Komposisi Pangan Indonesia. PT Elex Media Komputindo.

Miskiyah, Winarti, C. \& Broto, W. (2010). Kontaminasi mikotoksin pada buah segar dan produk olahannya serta penanggulangannya. Jurnal Penelitian dan Pengembangan Pertanian, 29(3), 79-85. doi:10.21082/jp3.v29n3.2010.p.

Permata, A.N. (2018). Uji kualitas mikrobiologi dan identifikasi kapang kontaminan pada biji 
ketumbar (Coriandrum sativum L.) yang dijual di pasar tradisional Kota Malang. State University of Malang. http://repository.um.ac.id/26881/.

Pitt, J. \& Hocking, A. (1985). Fungi and Food Spoilange, Food Science and Technology. Australia: Academic Press.

Qomariah, U.K.N., Hastuti, U.S. \& Witjoro, A. (2012). Isolasi dan identifikasi spesies kapang kontaminan pada biji kacang. Pros Semin Nas Penelitian, Pendidikan, dan Penerapan Fakultas MIPA, Universitas Negeri Yogyakarta, 34-40.

Rakhmawati, A. (2009). Isolasi dan identifikasi kapang kontaminan pada kacang tanah (Arachis hypogaea L) yang dijual di pasar Beringharjo Yogyakarta. Berkala Penelitian Hayati Ed Khusus 3C, 9-14.

Samson, R.A., Hoekstra, E.S. \& Van Oorschot, C.A.N. (1984). Introduction to Food-Borne Fungi. Second Ed. Centraal Bureau voor Schimmelcultures, Baarn, Netherlands.

Sandoval-Denis, M., Gené, J., Sutton, D.A., Cano-Lira, J.F., de Hoog, G.S., Decock, C.A., Wiederhold, N.P. \& Guarro, J. (2016). Redefining Microascus, Scopulariopsis and allied genera. Persoonia 36, 1-36. doi:10.3767-/003158516X688027.

Sandoval-Denis, M., Sutton, D.A., Fothergil, A.W., Cano-Lira, J., Gené, J., Decock, C.A., De Hoog, G.S. \& Guarro, J. (2013). Scopulariopsis, a poorly known opportunistic fungus: Spectrum of species in clinical samples and in vitro responses to antifungal drugs. $J$ Clin Microbiol., 51(12), 3937-3943. doi:10.1128/JCM.01927-13.

Suparyati, T. \& Supriyo. (2015). Perbandingan kontaminasi jamur Aspergillus sp. pada kacang kedelai berbiji kuning kualitas baik dan jelek yang dijual di Pasar Wiradesa, Kab. Pekalongan. Pena J Ilmu., 26(2), 134-139.

Widiastuti, R. (2006). Mikotoksin: Pengaruh terhadap kesehatan ternak dan residunya dalam produk ternak serta pengendaliannya. Wartazoa, 16(3), 116-127.

Widowati, S. (2013). Teknologi Pengolahan Kedelai. Monograf Kedelai Balitkabi. 